\title{
Rumen parameters and passage rate in cattle fed diets based on sugarcane hydrolyzed with calcium oxide
}

\section{Parâmetros ruminais e taxa de passagem em bovinos alimentados com rações baseadas em cana de açúcar hidrolisada com óxido de cálcio}

\author{
Fernando César Ferraz Lopes ${ }^{1}$; Mariana Magalhães Campos²*; \\ Ana Luiza da Costa Cruz Borges ${ }^{3}$; Carlos Giovani Pancoti ${ }^{4}$; \\ Ricardo Reis e Silva ${ }^{5}$; Tainá Silvestre Moreira ${ }^{6}$
}

\begin{abstract}
Nine non-lactating Holstein x Gyr cattle were fed with rations based on chopped sugarcane supplied in natura (control) or hydrolyzed (fresh matter basis) for $24 \mathrm{~h}$ with $1 \%$ or $2 \%$ calcium oxide $(\mathrm{CaO})$, which corresponds to $3.1 \%$ or $6.2 \% \mathrm{CaO}$ on a dry matter (DM) basis, respectively. Ruminal parameters (pH and ammonia $\mathrm{N}$, acetate, propionate and butyrate concentrations) as well as the kinetics of fluid and particulate passage in the gastrointestinal tract from cattle were evaluated. A design using three 3 x 3 contemporaneous Latin Squares (LS) was adopted. The studies of kinetics of fluid and particulate passage were performed using the external markers cobalt-EDTA and chromium-mordanted-NDF, respectively. The ruminal parameters were analyzed according to a $3 \times 3 \mathrm{LS}$ replicated three times with repeated measures in time using mixed models that included the fixed effects of treatment (level of $\mathrm{CaO}$ ), time of sampling and their interaction and the following random effects: LS, animal(LS), period of LS and period*animal (LS). The kinetic parameters of fluid and particulate passage were analyzed using mixed models with treatment as a fixed effect and period of LS, animal(LS) and LS as random effects. The linear and quadratic effects of the treatments were analyzed using orthogonal contrasts. Significant differences were declared at $\mathrm{P} \leq 0.05$. No treatment*time interaction was observed $(\mathrm{P}>$ $0.05)$ for any ruminal parameter. A linear effect $(\mathrm{P}=0.0279)$ of $\mathrm{CaO}$ inclusion on ruminal $\mathrm{pH}$ was observed, but there were no effects $(\mathrm{P}>0.05)$ of the treatments on the ammonia $\mathrm{N}$, acetate, butyrate and total volatile fatty acid ruminal concentrations. There was a quadratic effect $(\mathrm{P}=0.05)$ of the addition of $\mathrm{CaO}$ on the ruminal propionate concentration. There was no effect $(\mathrm{P}>0.05)$ of the treatments on the particulate rate of passage in the rumen as well as on the mean retention time in this compartment and in the total gastrointestinal tract. On the other hand, the addition of $\mathrm{CaO}$ to sugarcane promoted a linear increase $(\mathrm{P}=0.0258)$ in the particulate post-ruminal passage rate and, consequently, a linear reduction $(\mathrm{P}=0.0363)$ of the mean retention time in the cecum-proximal colon. There was no effect $(\mathrm{P}$ $>0.05$ ) of the sugarcane hydrolysis with $\mathrm{CaO}$ on the ruminal parameters of the kinetics of fluid passage (dilution rate, retention time and turnover rate). The addition of $3.1 \%$ or $6.2 \% \mathrm{CaO}$ on a DM basis $(1 \%$
\end{abstract}

1 Analista, Embrapa Gado de Leite, Juiz de Fora, MG, Brasil. E-mail: fernando.lopes@embrapa.br

2 Pesquisadora, Embrapa Gado de Leite, Juiz de Fora, MG, Brasil. E-mail: mariana.campos@embrapa.br

3 Prof ${ }^{\mathrm{a}}$ Associado, Departamento de Zootecnia, Escola de Veterinária, Universidade Federal de Minas Gerais, UFMG, Belo Horizonte, MG, Brasil. E-mail: analuizavetufmg@gmail.com

4 Médico Veterinário, Dr. em Zootecnia, Agroceres, Agroceres Multimix, Rio Claro, SP, Brasil. E-mail: carlos.pancoti@agroceres.com

5 Prof. Adjunto, Departamento de Zootecnia, Escola de Veterinária, UFMG, Belo Horizonte, MG, Brasil. E-mail: ricreis1@ hotmail.com

6 Bióloga, Dr ${ }^{\mathrm{a}}$ em Nutrição e Produção Animal, Faculdade de Medicina Veterinária e Zootecnia, Universidade de São Paulo, USP, Pirassununga, SP, Brasil. E-mail: taina.tr@gmail.com

* Author for correspondence 
or $2 \% \mathrm{CaO}$ on a fresh matter basis, respectively) of sugarcane does not improve ruminal fermentation, nor does it increase the fluid or particulate passage in the rumen of non-lactating Holstein x Gyr cattle. Key words: Alcali. Bovine. Lime. pH. Saccharum officinarum. Volatile fatty acids.

\section{Resumo}

Nove fêmeas Holândês x Gir não lactantes, alocadas em três Quadrados Latinos (QL) 3 x 3 contemporâneos, foram alimentadas com rações à base de cana de açúcar picada, fornecida in natura (Controle) ou hidrolisada (base da matéria fresca) por $24 \mathrm{~h}$ com $1 \%$ ou $2 \%$ de óxido de cálcio $(\mathrm{CaO})$, o que correspondeu, respectivamente, a $3,1 \%$ ou $6,2 \%$ de $\mathrm{CaO}$ com base na matéria seca (MS). O $\mathrm{pH}$ e as concentrações ruminais de $\mathrm{N}$ amoniacal, acetato, propionato e butirato foram avaliados. As cinéticas de passagem de fluidos e de partículas no trato gastrointestinal (TGI) dos animais foram estudadas utilizando, respectivamente, os indicadores externos Cobalto-EDTA e fibra em detergente neutro mordantada com Cromo. As análises estatísticas foram realizadas utilizando modelos mistos. Os parâmetros de fermentação ruminal foram analisados como medidas repetidas no tempo, sendo considerados efeitos fixos: o tratamento (nível de adição de $\mathrm{CaO}$ ), o tempo de amostragem e sua interação, e efeitos aleatórios: QL, animal(QL), período do QL e período*animal(QL). Os parâmetros de cinética de fluidos e de partículas no TGI foram analisados considerando o tratamento como efeito fixo, e período do QL, animal(QL) e QL como efeitos aleatórios. Diferenças foram consideradas significativas quando $\mathrm{P} \leq 0,05$. Não houve interação tratamento*tempo $(\mathrm{P}>0,05)$ para nenhum parâmetro ruminal. A adição de $\mathrm{CaO}$ promoveu incremento linear $(\mathrm{P}=0,0279)$ no $\mathrm{pH}$ do rúmen, mas não houve efeito $(\mathrm{P}>0,05)$ dos tratamentos sobre as concentrações ruminais de $\mathrm{N}$ amoniacal, acetato, butirato e ácidos graxos voláteis totais. Foi observado efeito quadrático $(\mathrm{P}=0,05)$ da adição de $\mathrm{CaO}$ sobre a concentração ruminal de propionato. Não houve efeito $(\mathrm{P}>0,05)$ dos tratamentos na taxa de passagem de partículas no rúmen, bem como no tempo médio de retenção neste compartimento e no TGI. Por outro lado, a adição de $\mathrm{CaO}$ à cana de açúcar promoveu incremento linear $(\mathrm{P}=0,0258)$ na taxa de passagem pós-ruminal de partículas e, consequentemente, houve redução linear $(\mathrm{P}=0,0363)$ no tempo médio de retenção no ceco-cólon proximal. Não houve efeito $(\mathrm{P}>0,05)$ da hidrólise da cana de açúcar com $\mathrm{CaO}$ sobre os parâmetros da cinética da passagem de fluidos no rúmen (taxa de diluição, tempo de retenção e taxa de reciclagem). A adição de $1 \%$ ou $2 \%$ de $\mathrm{CaO}$ na matéria fresca (respectivamente, $3,1 \%$ ou $6,2 \%$ na matéria seca) da cana de açúcar não melhora a fermentação ruminal nem aumenta as taxas de passagem de fluidos e de partículas no rúmen de bovinos Holandês x Gir não lactantes.

Palavras-chave: Ácidos graxos voláteis. Álcali. Bovino. Cal. pH. Saccharum officinarum.

\section{Introduction}

Sugarcane (Saccharum officinarum L.) is a source of roughage traditionally used in the seasonal period of tropical grass production in milk production systems of Brazil (CAMPOS et al., 2017).

However, despite the high production of forage with a high energy value, due to the high content of soluble carbohydrates (sucrose) in the stalks, sugarcane presents nutritional limitations that restrict its use as an exclusive ingredient in the ruminant diet (CAMPOS et al., 2017). For cows with a milk yield of $\sim 21 \mathrm{~kg} \mathrm{day}^{-1}$, the limitation of the low crude protein content of sugarcane forage can be corrected by the inclusion of non-protein $\mathrm{N}$ sources, such as urea, in diets with $50 \%$ of concentrates (SOUZA et al., 2015).

However, perhaps the most challenging nutritional limitation of sugarcane for its inclusion in the diet of high-producing ruminants is the low digestibility of its fiber, a consequence of the high rumen-undegradable neutral detergent fiber (NDF) content of its forage combined with the low ruminal digestion rate of the potentially degradable NDF (SANTOS et al., 2011; RIBEIRO et al., 2015; CAMPOS et al., 2017). These fractions have a 
high effect of rumen fill and are responsible for the reduction in the rate of passage of the digesta (RIBEIRO et al., 2015) and voluntary consumption of sugarcane-based diets, with a negative impact on animal performance (SANTOS et al., 2011).

The effect of alkalinizing agents, such as sodium hydroxide $(\mathrm{NaOH})$, calcium hydroxide $\left(\mathrm{Ca}(\mathrm{OH})_{2}\right)$ and, more recently, calcium oxide $(\mathrm{CaO})$, on the digestibility of the fibrous fraction of sugarcane has been evaluated in studies conducted in vitro (MOTA et al., 2010; DOMINGUES et al., 2015) and in vivo in cattle (EZEQUIEL et al., 2005; MORAES et al., 2008; PINA et al., 2010; CAMPOS et al., 2011; FREITAS et al., 2011; PINA et al., 2011; MISSIO et al., 2012; DANIEL et al., 2013). In theory, these alkalis promote the breakdown of the cell wall and the partial solubilization of the hemicelluloses, lignin and silica, through the hydrolysis of uronic esters and acetic acid and the swelling of cellulose (JACKSON, 1977). Potentially, this may promote an increase in the ruminal passage rate of the digesta and consequently in the voluntary consumption of diets based on sugarcane, resulting in a greater availability of nutrients for maintenance and production.

There are few studies on ruminal fermentation parameters of digesta and the kinetics of fluid and particulate passage in the gastrointestinal tract of cattle fed with rations based on hydrolyzed sugarcane. As summarized by Seo et al. (2006), the rate of passage of fluids in the rumen may affect the digestion of soluble nutrients (e.g., sucrose), outflow of the end products of fermentation (e.g., volatile fatty acids - VFAs), peptide escape and microbial growth. In turn, the particulate rate of passage in the rumen is related to voluntary feed intake, extent of digestion of the diet, the site of protein digestion, efficiency of microbial growth, etc. Therefore, in models designed to evaluate diets and cattle performance based on relationships between the nutritional components of the digesta and the nutrient supply, information on the kinetics of fluid and particulate passage is fundamental to allow the modeling of rumen function and metabolism using mathematical equations and quantitative representations (SEO et al., 2006; TYLUTKI et al., 2008; VAN AMBURGH et al., 2015).

The results of $\mathrm{pH}$ and ammonia $\mathrm{N}$ concentration in the rumen of cattle were presented in studies performed with sugarcane hydrolyzed with calcium hydroxide (DIAS et al., 2012; MISSIO et al., 2012) or calcium oxide (MORAES et al., 2008; PINA et al., 2010; SILVA JÚNIOR, 2013). However, VFA concentrations in the rumen of cattle fed hydrolyzed sugarcane-based diets were evaluated only in the studies of Dias et al. (2012) and Silva Júnior (2013), which were carried out using calcium hydroxide and $\mathrm{CaO}$ as alkalizing agents, respectively. The article by Ezequiel et al. (2005), which used sodium hydroxide, was the only work that evaluated the effect of alkaline hydrolysis of sugarcane on the kinetics of particulate passage in the gastrointestinal tract of cattle. On the other hand, Silva Júnior (2013) did not observe the effect of the sugarcane hydrolysis with $1 \% \mathrm{CaO}$ (fresh matter basis) on the kinetics of fluid passage in the rumen of cattle. However, there is no work of this type where a higher level of inclusion of $\mathrm{CaO}$ has been studied.

The aim of this study was to evaluate the ruminal fermentation parameters and the kinetics of fluid and particulate passage in the gastrointestinal tract of non-lactating Holstein x Gyr cattle fed with rations based on chopped sugarcane supplied in natura or hydrolyzed (fresh matter basis) with $1 \%$ or $2 \% \mathrm{CaO}(3.1 \%$ or $6.2 \% \mathrm{CaO}$ on a dry matter basis, respectively).

\section{Material and Methods}

The study was carried out at Embrapa Dairy Cattle in Valença (RJ), Brazil. All experimental procedures with animals were carried out according to the Embrapa Dairy Cattle guidelines for animal care and use in research. 
Nine non-lactating Holstein $\mathrm{x}$ Gyr cattle were used (body weight $=440 \pm 96 \mathrm{~kg}$ ), each provided with ruminal cannula with an internal opening diameter of $110 \mathrm{~mm}$. The animals were kept in a tie-stall type confinement system, each equipped with an individual trough and automatic drinking fountain.

A design using three $3 \times 3$ contemporaneous Latin Squares (LS) was adopted. Each period consisted of 21 days, with 14 and seven days for adaptation to the rations and the collections, respectively. The animals were homogeneously allocated to the LS based on body weight.

Three rations based on chopped sugarcane as the only roughage were evaluated (Table 1$)$. The sugarcane was supplied in natura (control) or hydrolyzed (fresh matter basis) with $1 \%$ or $2 \%$ $\mathrm{CaO}$, which corresponded to $3.1 \%$ or $6.2 \% \mathrm{CaO}$ on a $\mathrm{DM}$ basis, respectively. The $\mathrm{CaO}$ was supplied in a microprocessed form with low levels of dioxins, furans and magnesium. The treatment of the sugarcane with $\mathrm{CaO}$ was always performed $24 \mathrm{~h}$ prior to feeding the animals.

Table 1. Chemical composition of the diets expressed as a percentage of dry matter (\% DM).

\begin{tabular}{lccc}
\hline Nutrient & \multicolumn{3}{c}{ \% CaO added to sugarcane (DM basis) $^{1}$} \\
\cline { 2 - 4 } (\% DM) & 0 & 3.1 & 6.2 \\
\hline Dry matter (\%, fresh basis) & 33.18 & 34.52 & 35.34 \\
Organic matter & 88.63 & 83.29 & 80.10 \\
Ether extract & 1.40 & 1.13 & 0.98 \\
Non-fibrous carbohydrates & 46.13 & 42.91 & 41.22 \\
Neutral detergent fiber (NDF) & 33.00 & 32.84 & 32.51 \\
NDF corrected for ash and protein & 31.75 & 30.95 & 29.92 \\
Acid detergent fiber & 23.27 & 20.77 & 19.84 \\
Lignin & 4.71 & 4.03 & 3.62 \\
Cellulose & 18.57 & 16.74 & 16.22 \\
Hemicelluloses & 9.72 & 12.07 & 12.67 \\
Crude protein & 9.35 & 8.30 & 7.99 \\
Ash & 11.37 & 16.71 & 19.90 \\
Calcium (Ca) & 0.30 & 2.01 & 3.55 \\
Phosphorous $(\mathrm{P})$ & 0.19 & 0.20 & 0.20 \\
Ratio Ca: $\mathrm{P}$ & 1.55 & 10.70 & 19.77 \\
\hline
\end{tabular}

${ }^{1}$ Corresponds to $0 \%, 1 \%$ or $2 \% \mathrm{CaO}$ in the fresh matter of sugarcane, respectively.

The roughage: concentrate ratio of the rations (DM basis) was 75\%:25\%. The rations were provided to the animals twice a day, at $8 \mathrm{~h} 00$ and $14 \mathrm{~h} 00$, in sufficient amounts to allow for $10 \%$ of leftovers. The concentrate supplied had the following ingredient composition (as fed): 50\% soybean meal, 42\% corn meal, 5\% urea: ammonium sulphate mixture (9:1), and $3 \%$ mineral supplement. The macroand micromineral concentrations of the mineral supplement and of $\mathrm{CaO}$ are shown in Table 2 .
The RB-73-9735 variety of sugarcane was used, which has a productivity estimated at $150 \mathrm{t} \mathrm{ha}^{-1}$, medium maturation, rare flowering, and a harvest period between June and October. The sugarcane presented a mean Brix value of $22^{\circ}$. The formulation of the experimental rations was based on the nutritional requirements of the animals, determined according to the NRC (2001). 
Table 2. Mineral composition of the mineral supplement and calcium oxide $(\mathrm{CaO})$.

\begin{tabular}{lcccccccc}
\hline & \multicolumn{3}{c}{ Macromineral (\% of DM) } & \multicolumn{4}{c}{ Micromineral (ppm) } \\
\cline { 2 - 8 } Item & $\mathrm{Ca}$ & $\mathrm{Mg}$ & $\mathrm{P}$ & $\mathrm{K}$ & $\mathrm{Cu}$ & $\mathrm{Zn}$ & $\mathrm{Fe}$ & $\mathrm{Mn}$ \\
\hline Mineral supplement & 9.6 & 1.0 & 8.7 & 0.08 & 1,254 & 4,228 & 5,258 & 427 \\
$\mathrm{CaO}$ & 44.5 & 0.3 & 2.9 & 0.05 & 41 & 73 & 1,388 & 128 \\
\hline
\end{tabular}

$\mathrm{Ca}=$ Calcium; $\mathrm{Mg}=$ Magnesium; $\mathrm{P}=$ Phosphorous; $\mathrm{K}=$ Potassium; $\mathrm{Cu}=$ Copper; $\mathrm{Mn}=$ Manganese $\mathrm{Fe}=\mathrm{Iron}$ and $\mathrm{Zn}=\mathrm{Zinc}$.

On the $15^{\text {th }}$ day of each period of the LS, samples of ruminal fluid were collected from the ventral portion of the rumen prior to the morning feeding, and this was considered as time 0 (zero). Additional samples were obtained at $2,4,6,8,10,12,14,16$, 18, 20, 22 and $24 \mathrm{~h}$ after the first collection. The samples were filtered immediately using double gauze, and the $\mathrm{pH}$ was measured using a portable digital potentiometer. Two $50-\mathrm{mL}$ aliquots were then pipetted, added to flasks with $1 \mathrm{~mL}$ of $\mathrm{H}_{2} \mathrm{SO}_{4}$ $50 \% \mathrm{v} / \mathrm{v}$ (subsample 1) or $10 \mathrm{~mL}$ of metaphosphoric acid 25\% v/v (subsample 2), and then frozen. After thawing, subsample 1 was analyzed for the ammonia $\mathrm{N}$ concentration according to the INCTCA N-007/1 method (DETMANN et al., 2012). Subsample 2 was centrifuged $(17,000 \times \mathrm{g}$ for 10 min) and analyzed for the molar concentration $\left(\mu \mathrm{mol} \mathrm{mL} \mathrm{m}^{-1}\right)$ of the acetate, propionate and butyrate using a gas chromatographer model 7820A (Agilent Technologies Inc., Santa Clara, USA) provided with a Nukol capillary column (30 m x $22 \mathrm{~mm}$ x $0.25 \mu \mathrm{m}$ ) connected to free fatty acids (SUPELCO, Bellefonte, PA, USA) and equipped with a flame ionization detector.

Fresh and hydrolyzed sugarcane samples were collected and submitted to hot extraction using a neutral commercial detergent obtaining, on average, $84 \%$ NDF. Those materials were subsequently complexed with sodium dichromate $\left(\mathrm{Na}_{2} \mathrm{Cr}_{2} \mathrm{O}_{7} \cdot 2 \mathrm{H}_{2} \mathrm{O}\right)$ according to the procedures reported by Udén et al. (1980), resulting in mordants with 3\% Cr (DM basis). In each period of LS before the animals were fed their meal, $100 \mathrm{~g}$ of $\mathrm{Cr}-$ mordanted NDF was intra-ruminally administered in a single dose to each animal and fecal samples were collected directly from the rectum at $0,6,12$, $18,24,36,48,60,72,84$ and $96 \mathrm{~h}$ after dosing with the marker. Fecal samples were dried in a forced-air oven at $55^{\circ} \mathrm{C}(72 \mathrm{~h})$, ground to pass through a $1-\mathrm{mm}$ screen and stored for analysis for $\mathrm{Cr}$ content using atomic absorption spectrophotometry according to the INCT-CA M-005/1 method (DETMANN et al., 2012).

The study of the kinetics of the fluids in the rumen was performed using the external marker cobalt-EDTA (17.2\% of cobalt (Co), DM basis), obtained according to the procedures reported by Udén et al. (1980). In each period of LS before the animals were fed their meal, each animal was intraruminally pulse-dosed with $10 \mathrm{~g}$ of Co-EDTA in a $200 \mathrm{~mL}$ aqueous solution (w/v). Subsequently, fecal samples were collected directly from the rectum at the same times as previously described. These samples were dried in a forced-air oven at $55^{\circ} \mathrm{C}(72$ h), ground to pass through a 1-mm screen and stored for analysis for Co content using atomic absorption spectrophotometry (UDÉN et al., 1980).

Individual fecal $\mathrm{Cr}$ and $\mathrm{Co}$ excretion curves were fitted to the multi-compartmental model proposed by Dhanoa et al. (1985) and to the two-compartment biexponential time-independent model described by Grovum and Williams (1973), respectively, using the procedure for non-linear models of SAS version 9.0.

The multi-compartmental model proposed by Dhanoa et al. (1985) was of the form: $Y=A * \exp (-$ $\left.\left.\mathrm{k}_{1} * \mathrm{~T}\right) * \exp \left\{-(\mathrm{n}-2) \exp \left[-\left(\mathrm{k}_{2}-\mathrm{k}_{1}\right)\right) \mathrm{T}\right]\right\}$, where $\mathrm{Y}(\mathrm{mg}$ $\mathrm{kg}^{-1} \mathrm{DM}$ ) is the fecal marker concentration at time $\mathrm{t}$ (h); $\mathrm{T}=\mathrm{t}-\mathrm{TT}$; TT is the transit time or time delay 
(h) between the marker administration and its first appearance in the feces; $\mathrm{k}_{1}\left(\% \mathrm{~h}^{-1}\right)$ is the passage rate from the reticulorumen; $\mathrm{k}_{2}\left(\% \mathrm{~h}^{-1}\right)$ is the passage rate from the cecum-proximal colon; $\mathrm{A}$ is a scale parameter dependent on $\mathrm{k}_{1}$; and $n$ is the number of compartments in the model ( 2 in this case, the reticulorumen and the cecum-proximal colon). Mean retention times in the reticulorumen (RMRT, h) and the cecum-proximal colon (CMRT, h) were calculated as $1 / \mathrm{k}_{1}$ and $1 / \mathrm{k}_{2}$, respectively. Total mean retention time (TMRT, h) was calculated as TMRT $=\mathrm{RMRT}+\mathrm{CMRT}+\mathrm{TT}$ (MENDOZA et al., 2016).

The ruminal fluid passage rate or dilution rate $(\mathrm{k}$, $\% \mathrm{~h}^{-1}$ ) was estimated from the Grovum and Williams (1973) model. The rumen-reticulum retention time (RT, h) was calculated as the reciprocal of the ruminal fluid passage rate (i.e., $1 / \mathrm{k}$ ), and the turnover rate (i.e., the number of times that the pool is completely recycled every $24 \mathrm{~h}$ ) was calculated as 24/RT (times day ${ }^{-1}$ ) as described by Silva et al. (2011).

The ruminal parameters were analyzed according to a $3 \times 3$ LS replicated three times with repeated measures in time using the MIXED procedure of SAS version 9.0. The model included the fixed effects of treatment (level of $\mathrm{CaO}$ ), time of sampling and their interaction as well as the following random effects: LS, animal(LS), period of LS and period*animal (LS). Ten covariance structures of residues were compared, and the choice of matrix was made based on the Akaike information criterion. The kinetic parameters of fluid and particulate passage were analyzed using mixed models considering treatment as a fixed effect and period of LS, animal(LS) and LS as random effects. The linear and quadratic effects of the treatments were analyzed using orthogonal contrasts. The results are reported as LS means, and effects were considered significant when $\mathrm{P} \leq 0.05$. Regression analyses of parameters of ruminal fermentation were performed (REG procedure of SAS) as a function of sampling time as well as treatment.

\section{Results and Discussion}

No treatment*time interaction was observed $(\mathrm{P}>0.05)$ for any ruminal parameter. In a statistical analysis of data from 20 published studies that included 55 treatment means conducted to evaluate the effect of the addition of $\mathrm{CaO}$ to fresh sugarcane, Daniel et al. (2013) observed that the alkaline nature of $\mathrm{CaO}$ linearly raised the sugarcane $\mathrm{pH}$. Similarly, the addition of the alkaline agent $\mathrm{CaO}$ to the sugarcane in the present study caused a linear increase $(\mathrm{P}=0.0279)$ in the $\mathrm{pH}$ ruminal values (Table 3). In a study carried out with Angus $\mathrm{x}$ Nellore crossbred cows fed sugarcane-based diets hydrolyzed (fresh basis) with $0.8 \%, 1.6 \%$ and $2.4 \%$ calcium hydroxide, Dias et al. (2012) also observed this effect, i.e., an increase in the $\mathrm{pH}$ ruminal values due to the alkalinizing power of calcium hydroxide. It should be noted that the DM content of sugarcane (27.43\%) used in the work of Dias et al. (2012) was similar to that of the present study, which was on average $27.6 \%$.

Regardless of the treatment, there was an effect of the sampling time on the ruminal $\mathrm{pH}$ of the animals $\left(\hat{y}=6.80839-0.03923 *\right.$ time $+0.00220 * t_{i m e}{ }^{2} ; R^{2}$ $=0.59 ; \mathrm{P}=0.02)$. Throughout the day, a minimum value of 6.6 was estimated, which is higher than the value of 6.0 that is considered the critical limit below which degradation of cellulose is inhibited (VALADARES FILHO; PINA, 2011). The ruminal $\mathrm{pH}$ values observed in the present experiment (Table 3) were in the range of 6.51 to 7.22 obtained by Dias et al. (2012) in the rumen of Angus x Nellore crossbred cows fed sugarcane-based diets that were either hydrolyzed $(0.8 \%, 1.6 \%$ and $2.4 \%$; fresh matter basis) or not with calcium hydroxide. In a study performed with Nellore heifers that were fed a diet with $20 \%$ concentrate and $80 \%$ sugarcane with or without treatment of $0.5 \%$ and $1.0 \% \mathrm{CaO}$ (fresh matter basis), Pina et al. (2010) observed ruminal $\mathrm{pH}$ values ranging from 6.18 to 6.81 , which can be considered close to those presented in Table 3. On the other hand, higher ruminal $\mathrm{pH}$ values (6.82 to 
6.96) were observed by Silva Júnior (2013) in Jersey or hydrolyzed for $24 \mathrm{~h}$ with $1 \% \mathrm{CaO}$ (fresh matter steers that were fed a diet with $30 \%$ concentrate basis). and $70 \%$ chopped sugarcane supplied in natura

Table 3. Parameters of ruminal metabolism from non-lactating Holstein $\mathrm{x}$ Gyr cattle fed sugarcane-based diets hydrolyzed with calcium oxide $(\mathrm{CaO})$.

\begin{tabular}{|c|c|c|c|c|c|c|}
\hline \multirow[t]{2}{*}{ Parameter } & \multicolumn{3}{|c|}{$\begin{array}{c}\% \mathrm{CaO} \text { added to sugarcane } \\
(\text { dry matter basis })^{1}\end{array}$} & \multirow{2}{*}{$\begin{array}{l}\text { Standard error } \\
\text { of the mean }\end{array}$} & \multicolumn{2}{|c|}{ P-value } \\
\hline & 0 & 3.1 & 6.2 & & Linear & Quadratic \\
\hline $\mathrm{pH}$ & 6.63 & 6.82 & 6.79 & 0.062 & 0.0279 & 0.0785 \\
\hline Ammonia $\mathrm{N}\left(\mathrm{mg} \mathrm{dL}^{-1}\right)$ & 12.04 & 12.04 & 11.70 & 0.967 & 0.8752 & 0.8657 \\
\hline Acetate $\left(\mu \mathrm{mol} \mathrm{mL} L^{-1}\right)$ & 31.63 & 33.83 & 31.76 & 4.309 & 0.7221 & 0.3137 \\
\hline Propionate $\left(\mu \mathrm{mol} \mathrm{mL} L^{-1}\right)$ & 11.36 & 9.14 & 9.93 & 1.458 & 0.1405 & 0.0500 \\
\hline Butyrate $\left(\mu \mathrm{mol} \mathrm{mL} L^{-1}\right)$ & 8.06 & 10.16 & 8.18 & 1.202 & 0.9983 & 0.1090 \\
\hline Volatile fatty $\operatorname{acids}^{2}\left(\mu \mathrm{mol} \mathrm{mL} L^{-1}\right)$ & 50.88 & 53.59 & 50.23 & 7.060 & 0.9719 & 0.3567 \\
\hline Acetate: propionate ratio & 2.92 & 4.09 & 3.37 & 0.151 & 0.0019 & $<0.0001$ \\
\hline \multicolumn{7}{|l|}{ Molar proportions (\%) } \\
\hline Acetate & 61.55 & 65.01 & 63.66 & 1.390 & 0.2323 & 0.1547 \\
\hline Propionate & 22.16 & 16.57 & 19.54 & 0.9126 & 0.2370 & $<0.0001$ \\
\hline Butyrate & 16.19 & 18.67 & 16.73 & 1.717 & 0.9315 & 0.2635 \\
\hline
\end{tabular}

${ }^{1}$ Corresponds to $0 \%, 1 \%$ or $2 \% \mathrm{CaO}$ in the fresh matter of sugarcane, respectively.

${ }^{2}$ Volatile fatty acids $=\Sigma$ concentrations of acetate + propionate + butyrate.

No effect on the ruminal concentration of ammonia $\mathrm{N}$ was observed $(\mathrm{P}>0.05)$ with the inclusion of $\mathrm{CaO}$ in the diets. The mean values obtained (Table 3) were greater than $10 \mathrm{mg} \mathrm{dL}^{-1}$, considered adequate to meet the net requirement of the microbiota that ferment fibrous carbohydrates in the rumen and preferably use ammonia $\mathrm{N}$ as a nitrogenous substrate for protein synthesis (VALADARES FILHO; PINA, 2011). The lack of an effect of sugarcane hydrolysis with $1 \% \mathrm{CaO}$ on the ruminal concentration of ammonia $\mathrm{N}$ was also observed in two other studies, with Nellore heifers (PINA et al., 2010) and Jersey steers (SILVA JÚNIOR, 2013) fed diets containing $11.0 \%$ to $12.1 \%$ crude protein (DM basis). The ruminal ammonia $\mathrm{N}$ concentrations observed in the present experiment (Table 3) are within the range of the 8.03 to $13.4 \mathrm{mg}$ $\mathrm{dL}^{-1}$ obtained by Pina et al. (2010) and Silva Júnior (2013).

There was no effect $(\mathrm{P}>0.05)$ of the inclusion of $\mathrm{CaO}$ on the concentration and molar proportions of acetate in the rumen of animals (Table 3). In a companion study performed concomitantly with the present study that used the same treatments and animals, Campos et al. (2011) did not observe an effect on the parameters of in situ ruminal degradability of the NDF of the sugarcane when adding $\mathrm{CaO}$. This explains, at least in part, the similarity in the ruminal concentrations of acetate observed in the present study (Table 3).

There was a quadratic effect of the addition of $\mathrm{CaO}$ on the concentration $(\mathrm{P}=0.05)$ and molar proportion $(\mathrm{P}<0.0001)$ of propionate in the rumen of the animals (Table 3). Throughout the day, the minimum ruminal concentration of propionate was $9.07 \mu \mathrm{mol} \mathrm{mL} \mathrm{m}^{-1}$, estimated when $1.27 \%$ of $\mathrm{CaO}$ was added to sugarcane $\left(\hat{\mathrm{y}}=1.48 *\right.$ time $^{2}-3.75 *$ time $\left.+11.45 ; \mathrm{R}^{2}=0.40 ; \mathrm{P}=0.0044\right)$. In a statistical analysis of 20 published studies conducted to evaluate the addition of $0-3 \%$ of $\mathrm{CaO}$ to fresh sugarcane, Daniel et al. (2013) observed a quadratic effect $(\mathrm{P}<0.01)$ on the concentration of non-fibrous 
carbohydrates (NFCs). After chopping and storing sugarcane under aerobic conditions, sugarcane soluble carbohydrates can be extensively oxidized by epiphytic microorganisms, as well as by plant cell metabolism itself (DANIEL et al., 2013).

The heat resulting from the $\mathrm{CaO}$ hydration reaction in the forage mass submitted to the hydrolysis can accelerate the sugarcane fermentation process. This promotes the reduction of the soluble carbohydrate content and, consequently, the NFCs. The quadratic effect observed in the NFC content in response to the addition of $\mathrm{CaO}$ to sugarcane can be explained as a function of the $\mathrm{CaO}$ dose used in the sugarcane hydrolysis (DANIEL et al., 2013). Thus, while using lower doses of $\mathrm{CaO}$ may promote a reduction in the NFC content, the addition of higher concentrations of $\mathrm{CaO}$ could inhibit microbial growth and metabolism of plant cells, thereby preserving the NFCs in sugarcane.

In this sense, in relation to chopped sugarcane in natura, Romão et al. (2013) observed a reduction in the content of the $\mathrm{A}+\mathrm{B} 1$ fractions of carbohydrates when the sugarcane was hydrolyzed with $0.75 \%$ $\mathrm{CaO}$. In addition to this, increases were observed in these contents when $2.25-4.0 \%$ of $\mathrm{CaO}$ was used in the hydrolysis. Using the equation $\hat{y}=421-$ $6.13 \mathrm{x}+0.227 \mathrm{x}^{2}(\mathrm{P}<0.01)$ obtained by Daniel et al. (2013), the lowest NFC content was estimated in the present study when $\sim 1.4 \%$ of $\mathrm{CaO}$ was added to the fresh matter of sugarcane. This corroborates the study of Romão et al. (2013), who reported that the preservation of NFC in hydrolyzed sugarcane occurred with the addition of $1.5 \%$ of $\mathrm{CaO}$.

In the present study, it is possible to suggest that the $\mathrm{CaO}$ dose used in the hydrolysis of sugarcane (DANIEL et al., 2013; ROMÃO et al., 2013) may be related to the quadratic effect observed in the concentration and the molar proportion of propionate in the rumen (Table 3). As shown in Table 1, in relation to the diet in which sugarcane in natura was supplied, cattle fed with hydrolyzed sugarcane inclusion had lower NFC contents and, consequently, less amount of substrate for fermentation to propionic acid in the rumen.

There was no effect $(\mathrm{P}>0.05)$ of the inclusion of $\mathrm{CaO}$ on the concentration and molar proportions of butyrate or in the total concentration of VFAs in the rumen of the animals (Table 3). The absence of an effect $(\mathrm{P}>0.05)$ on the total concentration of VFAs with the inclusion of $\mathrm{CaO}$ in sugarcane can be attributed to the similarity observed between treatments for the concentration of acetate, which is the major VFA in the rumen. The quadratic effect $(\mathrm{P}<0.0001)$ that the inclusion of $\mathrm{CaO}$ promoted in the acetate: propionate ratio (Table 3) was a consequence of the observed similarity between the treatments for acetate concentration $(\mathrm{P}>0.05)$ but was mainly modulated by the quadratic effect $(\mathrm{P}=0.05)$ that the $\mathrm{CaO}$ inclusion promoted in the ruminal concentration of propionate.

In general, the ruminal concentrations of acetate, propionate, butyrate and VFAs observed in the present study (Table 3) can be considered low when compared to those obtained in studies for the evaluation of alkalizing agents in sugarcanebased diets supplied to cattle (DIAS et al., 2012; SILVA JÚNIOR, 2013). These reduced ruminal concentrations of VFAs are probably a reflection of the low availability of fermentable substrate, represented by the low quality of the sugarcane fiber (SANTOS et al., 2011; RIBEIRO et al., 2015), as well as the reduction of the NFC content promoted by the hydrolysis with $\mathrm{CaO}$ (Table 1).

There was no effect $(\mathrm{P}>0.05)$ of the treatments on the particulate rate of passage in the rumen as well as on the mean retention time in this compartment (RMRT). In a companion paper performed concomitantly with the present study that used the same treatments and animals, Campos et al. (2011) did not observe an effect on the parameters of in situ ruminal degradability of the fibrous fractions (NDF and $\mathrm{ADF}$ ) of the sugarcane when adding $\mathrm{CaO}$. This explains, at least in part, the similarity between the treatments regarding the particulate rate of passage 
in the rumen (Table 4). Also, this shows that the treatment with $\mathrm{CaO}$ did not provide the expected benefits, mainly in relation to the mitigation of the negative impact of the typically low digestibility of the fibrous fraction of sugarcane on the particulate rate of passage in the rumen. In addition, this corroborates the results of the study by Daniel et al. (2013), where it was shown that the net hydrolysis of sugarcane fiber was not achieved with treatment of up to $3 \% \mathrm{CaO}$.

Table 4. Parameters of the kinetics of particulate passage in the gastrointestinal tract of non-lactating Holstein $\mathrm{x}$ Gyr cattle fed sugarcane-based diets hydrolyzed with increasing amounts of calcium oxide $(\mathrm{CaO})$.

\begin{tabular}{lcccccc}
\hline \multirow{2}{*}{ Parameter $^{1}$} & \% CaO added to sugarcane (dry matter basis) & Standard error & \multicolumn{2}{c}{ P-value } \\
\cline { 2 - 3 } & 0 & 3.1 & 6.2 & of the mean & Linear & Quadratic \\
\hline $\mathrm{k}_{1}\left(\% \mathrm{~h}^{-1}\right)$ & 3.82 & 3.56 & 3.46 & 0.4974 & 0.1816 & 0.7268 \\
\hline $\mathrm{k}_{2}\left(\% \mathrm{~h}^{-1}\right)$ & 6.45 & 6.22 & 7.95 & 0.6270 & 0.0258 & 0.0701 \\
\hline TT $(\mathrm{h})$ & 11.74 & 11.71 & 8.84 & 1.8680 & 0.0416 & 0.2347 \\
\hline RMRT $(\mathrm{h})$ & 27.09 & 31.26 & 30.98 & 5.1510 & 0.2012 & 0.5506 \\
\hline CMRT $(\mathrm{h})$ & 15.83 & 16.66 & 13.23 & 1.3479 & 0.0363 & 0.0559 \\
\hline TMRT $(\mathrm{h})$ & 54.66 & 58.51 & 53.06 & 3.4718 & 0.5879 & 0.0842 \\
\hline
\end{tabular}

${ }^{1}$ Parameters estimated from the adjustment of the data of fecal excretion of $\mathrm{Cr}$ to the model proposed by Dhanoa et al. $(1985)$ : $\mathrm{k}_{1}=$ rate of passage in the reticulorumen; $\mathrm{k}_{2}=$ rate of passage in the cecum-proximal colon; TT = transit time or time delay (h) between marker administration and its first appearance in the feces; RMRT $=$ mean retention time in the reticulorumen $\left(1 / \mathrm{k}_{1}\right), \mathrm{CMRT}=$ mean retention time in the cecum-proximal colon $\left(1 / \mathrm{k}_{2}\right)$; and TMRT (Total mean retention time) $=$ RMRT + CMRT + TT .

${ }^{2}$ Corresponds to $0 \%, 1 \%$ or $2 \% \mathrm{CaO}$ in the fresh matter of sugarcane, respectively.

The addition of $\mathrm{CaO}$ promoted a linear increase $(\mathrm{P}=0.0258 ; \hat{\mathrm{y}}=0.75 \mathrm{x}+6.12)$ on the particulate post-ruminal passage rate, which in comparison to the rumen passage rate, presents less impact and importance considering sugarcane-based diets. In addition, the consequent linear reduction $(\mathrm{P}=$ $0.0363 ; \hat{y}=-1.30 x+16.54)$ observed for the CMRT was not sufficient to promote any change in the TMRT (Table 4), whose values were within normal range considering the literature for non-lactating cattle fed with sugarcane-based diets (AROEIRA et al., 1993; FIGUEIRA et al., 1993).

There was no effect $(\mathrm{P}>0.05)$ of the sugarcane hydrolysis with $\mathrm{CaO}$ on the ruminal parameters of the kinetics of fluid passage (Table 5), as also observed by Silva Júnior (2013), who worked with Jersey steers fed with in natura or hydrolyzed sugarcane-based diets. The parameters obtained in the present study (Table 5) are within the normal range considering the literature for non-lactating cattle fed with sugarcane-based diets (SILVEIRA et al., 2009; SILVA JÚNIOR, 2013). As summarized by Seo et al. (2006), the rate of passage of fluids in the rumen may affect digestion of soluble nutrients (e.g., sucrose), outflow of the end products of fermentation (e.g., VFAs), peptide escape and microbial growth. In this way, one can expect that the metabolism and the supply of these nutrients were similar among the evaluated diets and therefore had little impact on animal performance. 
Table 5. Parameters of the kinetics of fluid passage in the rumen of non-lactating Holstein x Gyr cattle fed sugarcanebased diets hydrolyzed with increasing amounts of calcium oxide $(\mathrm{CaO})$.

\begin{tabular}{|c|c|c|c|c|c|c|}
\hline \multirow[t]{2}{*}{ Parameter } & \multicolumn{3}{|c|}{$\begin{array}{l}\% \mathrm{CaO} \text { added to sugarcane } \\
(\text { dry matter basis })^{1}\end{array}$} & \multirow{2}{*}{$\begin{array}{l}\text { Standard error } \\
\text { of the mean }\end{array}$} & \multicolumn{2}{|c|}{ P-value } \\
\hline & 0 & 3.1 & 6.2 & & Linear & Quadratic \\
\hline Ruminal fluid rate passage $\left(\% \mathrm{~h}^{-1}\right)$ & 6.45 & 6.45 & 7.76 & 0.8066 & 0.1519 & 0.3715 \\
\hline Rumen-reticulum retention time (h) & 18.35 & 16.25 & 13.17 & 2.2111 & 0.1021 & 0.5894 \\
\hline Turnover rate (times day ${ }^{-1}$ ) & 1.55 & 1.55 & 1.86 & 0.1936 & 0.1518 & 0.3733 \\
\hline
\end{tabular}

${ }^{1}$ Corresponds to $0 \%, 1 \%$ or $2 \% \mathrm{CaO}$ in the fresh matter of sugarcane, respectively.

\section{Conclusion}

The addition of $3.1 \%$ or $6.2 \% \mathrm{CaO}$ on a $\mathrm{DM}$ basis ( $1 \%$ or $2 \% \mathrm{CaO}$ on a fresh matter basis, respectively) of sugarcane did not improve ruminal fermentation, nor did it increase the fluid or particulate passage in the rumen of non-lactating Holstein x Gyr cattle.

\section{Acknowledgments}

To Escola de Veterinária da UFMG, Embrapa Gado de Leite, Fapemig, CNPq, Ical (Indústria de Calcinação Ltda.) and Prodap for the financial support.

\section{References}

AROEIRA, L. J. M.; SILVEIRA, M. I.; LIZIEIRE, R. S.; MATOS, L. L.; FIGUEIRA, D. G. Degradabilidade no rúmen e taxa de passagem da cana-de-açúcar mais uréia, do farelo de algodão e do farelo de arroz em novilhos mestiços Europeu x Zebu. Revista da Sociedade Brasileira de Zootecnia, Viçosa, MG, v. 22, n. 4, p. 552564, 1993.

CAMPOS, M. M.; BORGES, A. L. C. C.; LOPES, F. C. F.; PANCOTI, C. G.; SILVA, R. R. Degradabilidade in situ da cana-de-açúcar tratada ou não com óxido de cálcio, em novilhas leiteiras Holandês x Gir. Arquivo Brasileiro de Medicina Veterinária e Zootecnia, Belo Horizonte, v. 63, n. 6, p. 1487-1492, 2011.

CAMPOS, M. M.; LOPES, F. C. F.; PEREIRA, L. G. R.; MACHADO, F. S.; TOMICH, T. R. Cana-de-açúcar na alimentação de rebanhos leiteiros. In: SILVA, F. C.; ALVES, B. J. R.; FREITAS, P. L. (Org.). Sistema de produção mecanizada da cana-de-açúcar integrada à produção de energia e alimentos. Brasília: Embrapa, 2017 , v. 2, p. 900-938.
DANIEL, J. L. P.; SANTOS, M. C.; ZOPOLLATTO, M.; HUHTANEN, P.; NUSSIO, L. G. A data-analysis of lime addition on the nutritive value of sugarcane in Brazil. Animal Feed Science and Technology, Amsterdan, v. 184, n. 1-4, p. 17-23, 2013.

DETMANN, E.; VALADARES FILHO, S. C.; BERCHIELLI, T. T.; CABRAL, L. S.; LADEIRA, M. M.; SOUZA, M. A.; QUEIROZ, A. C.; SALIBA, E. O. S.; PINA, D. P.; AZEVEDO, J. A. G. Métodos para análise de alimentos. Visconde do Rio Branco: Suprema, 2012. $214 \mathrm{p}$.

DHANOA, M. S.; SIDDONS, R. C.; FRANCE, J.; GALE, D. L. A multicompartimental model to describe marker excretion patterns in ruminant faeces. British Journal of Nutrition, Cambridge, v. 53, n. 3, p. 663-671, 1985.

DIAS, A. M.; ÍTAVO, L. C. V.; DAMASCENO, J. C.; SANTOS, G. T.; NOGUEIRA, E.; ÍTAVO, C. C. B. F. Ruminal parameters of bovines fed diets based on sugar cane with doses of calcium hydroxide. Revista Brasileira de Zootecnia, Viçosa, MG, v. 41, n. 4, p. 963-969, 2012.

DOMINGUES, F. N.; OLIVEIRA, M. Dal S.; MOTA, D. A.; SANTOS, J.; MIRANDA, A. S.; OLIVEIRA, R. P. Chemical composition and in vitro digestibility of fresh sugarcane hydrolysed with calcium oxide $(\mathrm{CaO})$. Semina: Ciências Agrárias, Londrina, v. 36, n. 2, p. 1043-1054, 2015.

EZEQUIEL, J. M. B.; QUEIROZ, M. A. A.; GALATI, R. L.; MENDES, A. R.; PEREIRA, E. M. O.; FATURI, C.; NASCIMENTO FILHO, V. F.; FEITOSA, J. V. Processamento da cana-de-açúcar: efeitos sobre a digestibilidade, o consumo e a taxa de passagem. Revista Brasileira de Zootecnia, Viçosa, MG, v. 34, n. 5, p. 17041710, 2005.

FIGUEIRA, D. G.; AROEIRA, L. J. M.; RODRIGUEZ, N. M.; SAMPAIO, I. B. M.; LOPES, F. C. F.; TORRES, M. P. Dinâmica ruminal e pós-ruminal da cana-de-açúcar e do farelo de algodão em bovinos alimentados com 
farelo de algodão e cana-de-açúcar suplementada com três diferentes níveis de uréia. Arquivo Brasileiro de Medicina Veterinária e Zootecnia, Belo Horizonte, v. 45, n. 1, p. 71-80, 1993.

FREITAS, A. W. P.; ROCHA, F. C.; ZONTA, A.; FAGUNDES, J. L.; FONSECA, R.; ZONTA, M. C. M. Desempenho de novilhos recebendo dietas à base de canade-açúcar in natura ou hidrolisada. Revista Brasileira de Zootecnia, Viçosa, MG, v. 40, n. 11, p. 2532-2537, 2011.

GROVUM, W. L.; WILLIAMS, V. J. Rate of passage of digesta in sheep. 4. Passage of marker through the alimentary tract and the biological relevance of rateconstants derived from the changes in concentration of marker in faeces. British Journal of Nutrition, Cambridge, v. 30, n. 2, p. 313-329, 1973.

JACKSON, M. G. Review article: the alkali treatment of straws. Animal Feed Science and Technology, Amsterdan, v. 2, n. 2, p. 105-130, 1977.

MENDOZA, A.; CAJARVILlE, C.; REPETTO, J. L. Digestive response of dairy cows fed diets combining fresh forage with a total mixed ration. Journal of Dairy Science, Champaign, v. 99, n. 11, p. 8779-8789, 2016.

MISSIO, R. L.; OLIVEIRA, M. Dal S.; SFORCINI, M. P. R.; RENNÓ, F. P.; FREITAS JÚNIOR, J. E.; ELEJADE, D. A. G.; FERRARI, V. B.; ABUD, G. C. Digestion of feed fractions and intake of heifers fed hydrolyzed sugarcane stored for different periods. Revista Brasileira de Zootecnia, Viçosa, MG, v. 41, n. 7, p. 1737-1746, 2012.

MORAES, K. A. K.; VALADARES FILHO, S. C.; MORAES, E. H. B. K.; LEÃO, M. I.; VALADARES, R. F. D.; DETMANN, E.; NALON, P. M. Parâmetros nutricionais de novilhas de corte alimentadas com canade-açúcar tratada com óxido de cálcio e diferentes níveis de concentrado. Revista Brasileira de Zootecnia, Viçosa, MG, v. 37, n. 7, p. 1301-1310, 2008.

MOTA, D. A.; OLIVEIRA, M. D. C.; DOMINGUES, F. N.; MANZI, G. M.; FERREIRA, D. S.; SANTOS, J. Hidrólise da cana-de-açúcar com cal virgem ou cal hidratada. Revista Brasileira de Zootecnia, Viçosa, MG, v. 39, n. 6, p. 1186-1190, 2010.

NATIONAL RESEARCH COUNCIL - NRC. Nutrients requirements of dairy cattle. 7. ed. Washington: National Academy Press, 2001. 381 p.

PINA, D. S.; VALADARES FILHO, S. C.; AZEVÊDO, J. A. G.; BARBOSA, A. M.; VALADARES, R. F. D.; DETMANN, E. Efeitos da inclusão e dos tempos de exposição da cana-de-açúcar ao óxido de cálcio sobre os parâmetros digestivos e fisiológicos de novilhas nelores. Revista Brasileira de Zootecnia, Viçosa, MG, v. 39, n. 7, p. 1579-1586, 2010.

PINA, D. S.; VALADARES FILHO, S. C.; TEDESCHI, L. O.; BARBOSA, A. M.; AZEVÊDO, J. A. G.; VALADARES, R. F. D.; SOUZA, N. K. P.; FONSECA, M. A. Níveis de inclusão e tempo de exposição da canade-açúcar ao óxido de cálcio sobre parâmetros digestivos e o desempenho de novilhas Nelore. Revista Brasileira de Zootecnia, Viçosa, MG, v. 40, n. 3, p. 648-656, 2011.

RIBEIRO, R. C. O.; VILLELA, S. D. J.; VALADARES FILHO, S. C.; SANTOS, S. A.; RIBEIRO, K. G.; DETMANN, E.; ZANETTI, D.; MARTINS, P. G. M. A. Effects of roughage sources produced in a tropical environment on forage intake, and ruminal and microbial parameters. Journal of Animal Science, Champaign, v. 93, n. 5, p. 2363-2374, 2015.

ROMÃO, C. O.; CARVALHO, G. G. P.; LEITE, V. M.; SANTOS, A. S.; CHAGAS, D. M. T.; RIBEIRO, O. L.; PINTO, L. F. B.; OLIVEIRA, R. L. Fracionamento de carboidratos e degradabilidade ruminal da cana-deaçúcar tratada com óxido de cálcio. Arquivo Brasileiro de Medicina Veterinária e Zootecnia, Belo Horizonte, v. 65 , n. 2, p. 537-546, 2013.

SANTOS, S. A.; VALADARES FILHO, S. C.; DETMANN, E.; VALADARES, R. F. D.; RUAS, J. R. M.; AMARAL, P. M. Different forage sources for F1 Holstein x Gir dairy cows. Livestock Science, Amsterdan, v. 142, n. 1-3, p. 48-58, 2011.

SEO, S.; TEDESCHI, L. O.; LANZAS, C.; SCHWAB, C. G.; FOX, D. G. Development and evaluation of empirical equations to predict feed passage rate in cattle. Animal Feed Science and Technology, Amsterdan, v. 128, n. 1-2, p. 67-83, 2006.

SILVA JÚNIOR, B. A. Cana de açúcar associada à ureia e cal virgem na alimentação de bovinos leiteiros. 2013. Dissertação (Mestrado em Zootecnia) - Universidade Federal da Grande Dourados, Dourados, MS.

SILVA, J. J.; SALIBA, E. O. S.; AROEIRA, L. J. M.; RODRIGUÉZ, N. M.; SILVA, A. G. M. Indicadores de cinética ruminal em vacas Holandês x Zebu em lactação. Ciência Animal Brasileira, Goiânia, v. 12, n. 1, p. 1-7, 2011.

SILVEIRA, R. N.; BERCHIELLI, T. T.; CANESIN, R. C.; MESSANA, J. D.; FERNANDES, J. J. R.; PIRES, A. $\mathrm{V}$. Influência do nitrogênio degradável no rúmen sobre a degradabilidade in situ, os parâmetros ruminais e a eficiência de síntese microbiana em novilhos alimentados com cana-de-açúcar. Revista Brasileira de Zootecnia, Viçosa, MG, v. 38, n. 3, p. 570-579, 2009.

SOUZA, R. C.; REIS, R. B.; LOPEZ, F. C. F.; MOURTHE, M. H. F.; LANA, A. M. Q.; BARBOSA, F. A.; SOUSA, 
B. M. Efeito da adição de teores crescentes de ureia na cana-de-açúcar em dietas de vacas em lactação sobre a produção e composição do leite e viabilidade econômica. Arquivo Brasileiro de Medicina Veterinária e Zootecnia, Belo Horizonte, v. 67, n. 2, p. 564-572, 2015.

TYLUTKI, T. P.; FOX, D. G.; DURBAL, V. M.; TEDESCHI, L. O.; RUSSELL, J. B.; VAN AMBURGH, M. E.; OVERTON, T. R.; CHASE, L. E.; PELL, A. N. Cornell net carbohydrate and protein system: a model for precision feeding of dairy cattle. Animal Feed Science and Technology, Amsterdan, v. 143, n. 1-4, p. 174-202, 2008.

UDÉN, P., COLUCCI, P. E.; VAN SOEST, P. J. Investigation of chromium, cerium and cobalt as markers in digesta. Rate of passage studies. Journal of Science and Food Agricultural, Oxford, v. 31, n. 7, p. 625-632, 1980.

VALADARES FILHO, S. C.; PINA, D. S. Fermentação ruminal. In: BERCHIELLI, T. T.; VAZ PIRES, A.; OLIVEIRA, S. G. (Ed.). Nutrição de ruminantes. 2. ed. Jaboticabal: Funep, 2011. p. 161-191.

VAN AMBURGH, M. E.; COLLAO-SAENZ, E. A.; HIGGS, R. J.; ROSS, D. A.; RECKTENWALD, E. B.; RAFFRENATO, E.; CHASE, L. E.; OVERTON, T. R.; MILLS, J. K.; FOSKOLOS, A. The Cornell Net Carbohydrate and Protein System: Updates to the model and evaluation of version 6.5. Journal of Dairy Science, Champaign, v. 98, n. 9, p. 6361-6380, 2015. 